\title{
ОЦІНКА БІОЛОГІЧНИХ ЕФЕКТІВ ІНГАЛЯЦІЙНОГО ВПЛИВУ ЛИМОННОї КИСЛОТИ (ЕКСПЕРИМЕНТАЛЬНІ ДАНІ)
}

\author{
๑В. А. Туркіна, Н. Ф. Лукасевич, О. С. Корчинська, С. Ш. Жук \\ Львівський національний медичний університет імені Данила Галицького
}

РЕЗЮмЕ. Незважаючи на широке та багатотонажне застосування лимонної кислоти і, відповідно, активний виробничий контакт з нею працівників, зайнятих на виробництві, даних літератури щодо біологічних ефектів аерозолю порошку лимонної кислоти за інгаляційного впливу вкрай мало.

Мета - дослідити біологічні ефекти лимонної кислоти за однократного та багаторазового інгаляційного надходження з подальшим встановленням безпечних рівнів впливу.

Матеріал і методи. Експериментальне дослідження виконано на нелінійних білих щурах. Досліджуваний пре-

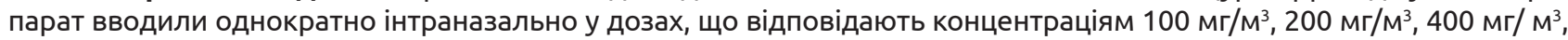
та упродовж 6-ти місяців у дозах, що відповідають концентраціям 30 мг/м³, 10 мг/м³, 3 мг/м³. Критеріями для визначення токсичної дії на організм тварин у експерименті були загальний стан тварин, морфологічні показники органів, гематологічні та біохімічні показники крові, показники перикисного окиснення ліпідів. Процеси оксидативного стресу оцінювали за показниками перекисного окиснення ліпідів. Вплив на глибокі дихальні шляхи оцінювали за цитологічним складом рідини бронхоальвеолярного лаважу.

Результати. Як свідчать результати досліджень, лимонна кислота при одноразовому та хронічному інгаляційному надходженні викликала одночасно порушення як функціонального стану дихальної системи, так і показників гемостазу, її можна віднести до речовин із неспецифічною подразнювальною дією. Результати біохімічних досліджень свідчать про виражений вплив лимонної кислоти на перебіг фізіолого-біохімічних процесів в організмі тварин у концентраціях 400 мг/м³ при однократному впливі та 30 мг/м³ при багаторазовому інгаляційному надходженні, які супроводжуються підвищенням активності сироваткових трансаміназ, вмісту загального білка і зниженням креатиніну. Також ці концентрації викликали зниження числа еритроцитів, рівня гематокриту та кількості ретикулоцитів. У бронхоальвеолярній рідині найвищі випробувані концентрації лимонної кислоти викликали зниження відсоткового вмісту макрофагів та підвищення лімфоцитів.

Висновки. Враховуючи встановлені параметри токсичності лимонної кислоти, величину порогу гострої інгаляційної дії встановлено на рівні $200 \mathrm{mr} / \mathrm{M}^{3}$, хронічної інгаляційної дії - $30 \mathrm{Mr} / \mathrm{M}^{3}$.

Характер токсичного ураження органів організмів піддослідних тварин при інгаляційному надходженні лимонної кислоти дозволяє віднести сполуку до речовин із неспецифічною подразнювальною дією.

КЛючовІ СЛОВА: лимонна кислота; інгаляційний вплив; порогові концентрації.

Вступ. Лимонна кислота широко застосується у різних галузях промисловості. Очікують, що до 2024 року глобальний ринок лимонної кислоти досягне майже 3 млн тонн. На сьогодні обсяги її виробництва посідають перше місце серед виробництва всіх органічних кислот [1]. В якості смакової добавки та консерванта (Е330) її широко застосовують у харчовій промисловості; завдяки властивостям антиокислювача і синергіста антиокислювачів лимонна кислота сьогодні використовується чи не в половині всіх продуктів, що випускаються харчовою промисловістю. Приблизно 15-17 \% виробленої в світі лимонної кислоти застосовується при виробництві миючих засобів, 7-9 \% - у косметичній та фармацевтичній промисловості, ще 6-8 \% - в інших галузях виробництва (зокрема у садівництві, хімічній, текстильній, шкірній, металургійній промисловості) [2].

Оцінка можливих токсичних ефектів екзогенної лимонної кислоти при надходженні per os та per cut за різної тривалості впливу висвітлена у низці наукових публікацій [3-5]. Аналіз даних літературних джерел свідчить, що лимонна кисло- та за критерієм гострої пероральної та інгаляційної токсичності належить до 4 класу небезпеки, не має місцево-подразнювальної дії при потраплянні на шкіру, але подразнює слизові оболонки, не встановлено сенсибілізувального ефекту в дослідах на тваринах. Міжнародне агентство з досліджень раку не вказує на канцерогенність лимонної кислоти для людини.

Щодо біологічних ефектів, які можуть виникнути в умовах виробництва за інгаляційного впливу аерозолю лимонної кислоти, дані літератури обмежені. Окрім того, незважаючи на широке та багатотонажне застосування й, відповідно, активний виробничий контакт із нею працівників, зайнятих на виробництві, в Україні на сьогодні ще не встановлені регламенти вмісту лимонної кислоти в повітрі робочої зони.

Мета - дослідити біологічні ефекти лимонної кислоти за однократного та багаторазового інгаляційного надходження з подальшим встановленням безпечних рівнів впливу.

Матеріал і методи дослідження. Хімічна назва сполуки за IUPAC: 2-гідроксипропан-1,2,3-три- 
Огляди літератури, оригінальні дослідження, погляд на проблему, випадок з практики, короткі повідомлення карбонова кислота. Міжнародна непатентована назва: лимонна кислота. Агрегатний стан: білий кристалічний порошок.

Експериментальна робота виконана на білих безпородних щурах-самицях віком 3-3,5 місяця та масою тіла 180-200 г, які утримувались в умовах віварію Львівського національного медичного університету імені Данила Галицького. Експериментальні тварини отримували стандартний гранульований корм із необмеженим доступом до питної води. Експериментальні роботи з тваринами були виконані відповідно до національних «Загальних етичних принципів експериментів на тваринах», які узгоджуються з положеннями «Європейської конвенції про захист хребетних тварин, що використовуються для експериментальних та інших наукових цілей» [6].

Досліджуваний препарат вводили однократно інтраназально у дозах, що відповідають концентраціям $100 \mathrm{Mr} / \mathrm{M}^{3}, 200 \mathrm{Mr} / \mathrm{M}^{3}, 400 \mathrm{Mr} / \mathrm{M}^{3}$ та упродовж 6-ти місяців у дозах, що відповідають концентраціям $30 \mathrm{Mr} / \mathrm{M}^{3}, 10 \mathrm{Mr} / \mathrm{M}^{3}, 3 \mathrm{Mr} / \mathrm{M}^{3}$.

Вплив на глибокі дихальні шляхи оцінювали за цитологічним складом рідини бронхоальвеолярного лаважу (БАЛ), яку отримували шляхом інфузії легень у розрахунку 1 мл фізіологічного розчину на 25 г ваги тіла тварини. Проби БАЛ охолоджували для аналізування та зберігання. Для цитологічного аналізу зразки БАЛ центрифугували впродовж 10 хвилин при 2000 об/хв, ресуспендували осад та виготовляли мазки, які фарбували за Романовським-Гімза. При мікроскопіюванні підраховували 200 клітин із кожного мазка [7].

Загальнотоксичну дію препарату на організм тварин вивчали за такими показниками: загальний стан тварин і клінічна картина отруєння, біохімічний аналіз крові з використанням стандартних тест-систем (виробник ТОВ «Філіцит-Діагностика», Україна) згідно з інструкцією, вміст гемоглобіну, еритроцитів, лейкоцитів у крові, лейкоцитарна формула за загальноприйнятими методиками.

Процеси оксидативного стресу оцінювали за показниками перекисного окиснення ліпідів (ПОЛ): активність каталази, вміст дієнових кон'югатів та малонового діальдегіду [8-10].

Статистичну обробку результатів проводили з використанням пакета програми Microsoft Excel. Перевірку відповідності отриманих даних нормальному закону розподілу проводили за критерієм Шапіро - Уілкса. За умови відповідності нормальності розподілу достовірність отриманих відмінностей порівнюваних величин оцінювали 3 використанням однофакторного дисперсійного аналізу (ANOVA) з наступним використанням багаторангового Тьюкі HSD-тесту або критерію Kruskal - Wallis із поправкою Бонфероні у випад-

ках, коли мав місце непараметричний розподіл даних. За достовірні приймали зміни з рівнем значимості більш ніж $95 \%(p<0,05)$ [11].

Результати та обговорення. Встановлено, що однократний інгаляційний вплив препарату в

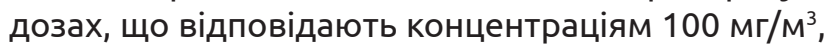
$200 \mathrm{mг} / \mathrm{M}^{3}, 400 \mathrm{мг} / \mathrm{M}^{3}$, не спричиняв загибелі піддослідних тварин, втрати апетиту або інших клінічних симптомів інтоксикації за виключенням незначного пригнічення дихальної та рухової активності упродовж 2-3 годин від початку експерименту.

У дослідних тварин, які зазнавали впливу препарату в концентрації 400 мг/м³ , на 2 добу статистично достовірно зменшувався рівень гемоглобіну; паралельно знижувалась кількість еритроцитів, рівень гематокриту та кількість ретикулоцитів: середній вміст еритроцитів знижувався на 20,2 \%, середній вміст гемоглобіну - на 21,1\%, спостерігалась тенденція до зменшення, але не вірогідного, кількості лейкоцитів, лімфоцитів, тромбоцитів, порівняно з аналогічними показниками тварин контрольної групи. У тварин виявлено тенденцію до збільшення активності АлАТ - на 18,9 \% та лужної фосфатази - на 13,2 \%, на противагу аналогічним показникам у контрольних тварин. Зміни решти досліджуваних показників не мали статистичної достовірності. При дії препарату в концентрації 200 мг/м³ у піддослідних тварин спостерігалось зменшення середнього вмісту гемоглобіну на 20,2 \%, еритроцитів - на 18,5 \%. Морфологічні показники крові та активність сироваткових ферментів при впливі препарату в концентрації 100 мг/м³ знаходились у межах фізіологічної норми (табл. 1).

Для оцінки пневмотоксичного ефекту було досліджено показники бронхоальвеолярної рідини. Найвища концентрація лимонної кислоти (400 мг/м³) спричинила зниження відсоткового вмісту макрофагів та підвищення - лімфоцитів;

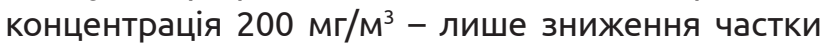
макрофагів. При концентрації препарату 100 мг/м³ реакції з боку клітин бронхолегеневого відділу не виявлено (рис. 1).

Результати дослідження рівнів первинних (дієнові кон'югати) і кінцевих (малоновий діальдегід) продуктів ПОЛ та активності антиокиснювальних ферментів (каталаза) бронхоальвеолярного лаважу представлено в таблиці 2.

У результаті досліджень було встановлено, що за гематологічними показниками та активністю трансфераз у крові, а також показниками «відсоткової частки макрофагів» і показниками ПОЛ поріг однократної інгаляційної дії складає 200 мг/м³.

Отже, оскільки сполука викликала одночасно порушення як функціонального стану дихальної 
Огляди літератури, оригінальні дослідження, погляд на проблему, випадок з практики, короткі повідомлення

Таблиця 1. Гематологічні та біохімічні показники крові білих щурів при однократному інтранзальному введенні лимонної кислоти

\begin{tabular}{|c|c|c|c|c|}
\hline \multirow{2}{*}{ Показники } & \multirow{2}{*}{ Контроль } & \multicolumn{3}{|c|}{ Експериментальні групи } \\
\hline & & $100 \mathrm{Mr} / \mathrm{M}^{3}$ & $200 \mathrm{Mr} / \mathrm{M}^{3}$ & $400 \mathrm{Mr} / \mathrm{M}^{3}$ \\
\hline Гемоглобін, г/л & $161,4 \pm 4,22$ & $154,8 \pm 8,34$ & $141,2 \pm 3,05^{*}$ & $130,1 \pm 8,12^{*}$ \\
\hline Гематокрит, л/л & $0,434 \pm 0,03$ & $0,429 \pm 0,09$ & $0,399 \pm 0,06$ & $0,313 \pm 0,055^{*}$ \\
\hline Еритроцити, Т/л & $5,12 \pm 0,22$ & $5,30 \pm 0,3$ & $4,19 \pm 0,17^{*}$ & $4,11 \pm 0,21 *$ \\
\hline АЛТ, ммоль/год.л & $2,8 \pm 0,18$ & $3,1 \pm 0,15$ & $3,24 \pm 1,14$ & $3,39 \pm 0,23$ * \\
\hline АСТ, ммоль/год.л & $1,43 \pm 0,91$ & $1,50 \pm 1,05$ & $1,55 \pm 0,67$ & $1,52 \pm 0,57$ \\
\hline Сечовина, ммоль/л & $4,6 \pm 0,23$ & $4,5 \pm 0,40$ & $4,49 \pm 0,35$ & $4,54 \pm 0,19$ \\
\hline Креатинін, мкмоль/л & $39,79 \pm 0,56$ & $39,50 \pm 0,49$ & $38,40 \pm 1,0$ & $31,2 \pm 1,99 *$ \\
\hline Лужна фосфатаза, Е/л & $270,55 \pm 16,8$ & $272,55 \pm 14,1$ & $285,30 \pm 12,1$ & $315,30 \pm 15,7 *$ \\
\hline Загальний білок, г/л & $64,6 \pm 1,98$ & $65,4 \pm 1,60$ & $66,3 \pm 1,9$ & $75,01 \pm 1,8^{*}$ \\
\hline Лейкоцити, Г/л & $7,2 \pm 0,42$ & $6,90 \pm 0,35$ & $6,78 \pm 0,51$ & $6,4 \pm 0,53$ \\
\hline Базофіли, \% & 0 & 0 & 0 & 0 \\
\hline Еозинофіли, \% & $0,38 \pm 0,01$ & $0,33 \pm 0,05$ & $0,35 \pm 0,03$ & $0,4 \pm 0,07$ \\
\hline Паличкоядерні, \% & $5,9 \pm 0,66$ & $6,1 \pm 0,89$ & $6,3 \pm 0,77$ & $5,8 \pm 0,59$ \\
\hline Сегментоядерні, \% & $22,3 \pm 2,98$ & $23,3 \pm 2,69$ & $22,8 \pm 2,79$ & $23,8 \pm 1,80$ \\
\hline Моноцити, \% & $1,9 \pm 0,56$ & $1,7 \pm 0,76$ & $2,0 \pm 0,98$ & $2,40 \pm 0,49$ \\
\hline Лімфоцити, \% & $52,3 \pm 2,48$ & $51,9 \pm 2,39$ & $51,0 \pm 3,10$ & $48,9 \pm 3,38$ \\
\hline Тромбоцити, $10^{9}$ /л & $450,1 \pm 21,44$ & $440,5 \pm 32,44$ & $448,0 \pm 30,05$ & $445,0 \pm 34,10$ \\
\hline
\end{tabular}

Примітка. *- достовірні відмінності від показників інших груп $(p \leq 0,05)$.

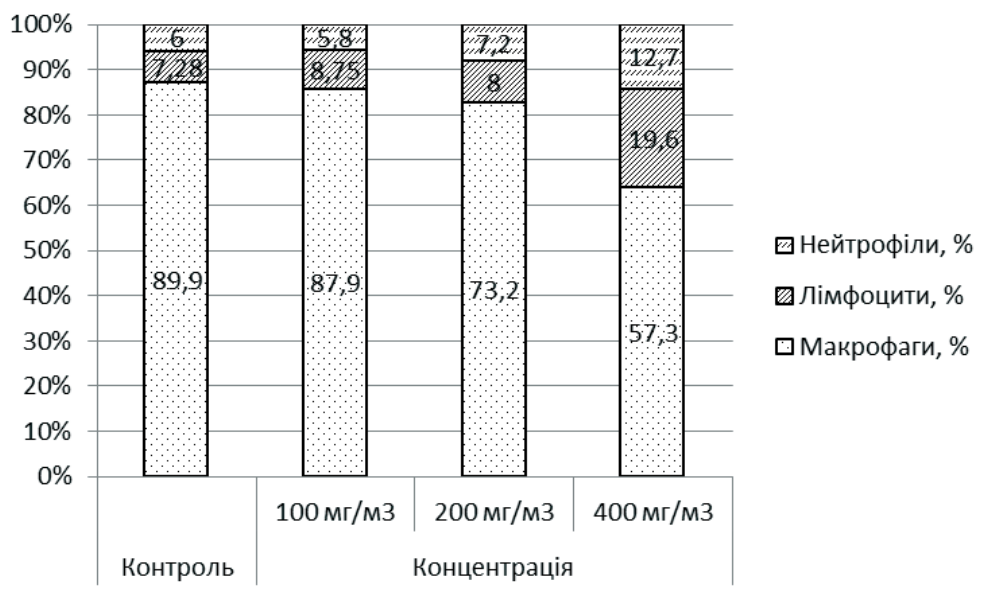

Рис. 1. Клітинний склад бронхоальвеолярного лаважу після однократної інтраназальної інстиляції лимонної кислоти білим щурам.

Таблиця 2. Показники ПОл бронхо-альвеолярного лаважу після однократної інтраназальної інстиляції лимонної кислоти білим щурам

\begin{tabular}{|l|c|c|c|c|}
\hline \multirow{2}{*}{ Показник } & \multirow{2}{*}{ Контроль } & \multicolumn{3}{|c|}{ Експериментальні групи } \\
\cline { 3 - 5 } & & $100 \mathrm{Mr} / \mathrm{M}^{3}$ & $200 \mathrm{Mr} / \mathrm{M}^{3}$ & $400 \mathrm{mг} / \mathrm{M}^{3}$ \\
\hline Дієнові кон'югати, у. о. & $9,3 \pm 0,7$ & $9,50 \pm 1,1$ & $8,9 \pm 0,8$ & $20,5 \pm 6,4^{*}$ \\
\hline Малоновий діальдегід, ммоль/ л & $0,97 \pm 0,47$ & $1,12 \pm 0,56$ & $1,37 \pm 0,62 *$ & $1,52 \pm 0,74 *$ \\
\hline Каталаза, мкат/л & $0,05 \pm 0,02$ & $0,05 \pm 0,01$ & $0,45 \pm 0,01$ & $0,02 \pm 0,001^{*}$ \\
\hline
\end{tabular}

Примітка. * - достовірні відмінності від показників інших груп $(p \leq 0,05)$.

системи, так і показників гемостазу, ії можна віднести до речовин із неспецифічною подразнювальною дією.
Вплив лимонної кислоти за умов хронічного інтраназального надходження не викликав вірогідних різниць показників маси тіла, 
Огляди літератури, оригінальні дослідження, погляд на проблему, випадок з практики, короткі повідомлення проте проявляв тенденцію до ії нижчого значення у піддослідних тварин, порівняно із тваринами контрольної групи. Проведене дослідження показало, що інтраназальне введення лимонної кислоти упродовж 6 місяців у дозах,

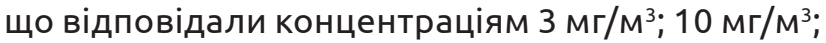

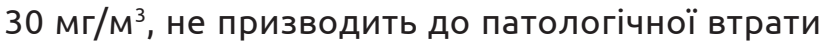
ваги (табл. 3).

Таблиця 3. Динаміка зміни ваги щурів при хронічній інтраназальній інстиляції лимонної кислоти

\begin{tabular}{|l|c|c|}
\hline \multicolumn{1}{|c|}{ Група } & Вага тварини до експерименту, г & Вага тварини після експерименту, г \\
\hline Контроль & $200,1 \pm 2,4$ & $245,4 \pm 6,4$ \\
\hline $3,0 \mathrm{Mr} / \mathrm{M}^{3}$ & $202,2 \pm 3,0$ & $220,4 \pm 4,2$ \\
\hline $10,0 \mathrm{Mr} / \mathrm{M}^{3}$ & $201,7 \pm 2,4$ & $224,5 \pm 5,7$ \\
\hline $30,0 \mathrm{Mr} / \mathrm{M}^{3}$ & $198,6 \pm 4,1$ & $238,3 \pm 5,9$ \\
\hline
\end{tabular}

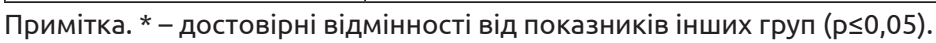

Як видно з таблиці 4, за хронічного впливу лимонної кислоти не виявлено вірогідно виражених міжгрупових відмінностей для більшості показників масових коефіцієнтів внутрішніх органів. Однак, встановлено вірогідно вищі по- казники коефіцієнта маси селезінки у щурів дослідної групи на тлі невірогідного зростання їх маси, порівняно з контрольною групою при впли-

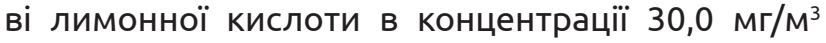
(табл. 4).

Таблиця 4. Масові коефіцієнти органів щурів при хронічній інтраназальній інстиляції лимонної кислоти

\begin{tabular}{|l|c|c|c|c|}
\hline \multirow{2}{*}{\multicolumn{1}{c|}{ Органи }} & \multirow{2}{*}{ Контроль } & \multicolumn{3}{c|}{ Експериментальні групи } \\
\cline { 3 - 5 } & & $3,0 \mathrm{Mr} / \mathrm{M}^{3}$ & $10,0 \mathrm{мг} / \mathrm{M}^{3}$ & $30,0 \mathrm{мг} / \mathrm{M}^{3}$ \\
\hline Серце & $0,322 \pm 0,013$ & $0,319 \pm 0,010$ & $0,318 \pm 0,007$ & $0,336 \pm 0,032$ \\
\hline Легені & $0,665 \pm 0,040$ & $0,664 \pm 0,048$ & $0,638 \pm 0,032$ & $0,662 \pm 0,066$ \\
\hline Шлунок & $0,584 \pm 0,041$ & $0,563 \pm 0,031$ & $0,554 \pm 0,029$ & $0,531 \pm 0,022$ \\
\hline Печінка & $3,000 \pm 0,112$ & $3,090 \pm 0,086$ & $2,877 \pm 0,064$ & $3,514 \pm 0,066^{*}$ \\
\hline Селезінка & $0,558 \pm 0,040$ & $0,548 \pm 0,071$ & $0,483 \pm 0,034$ & $0,720 \pm 0,062$ \\
\hline Ліва нирка & $0,338 \pm 0,006$ & $0,341 \pm 0,086$ & $0,332 \pm 0,008$ & $0,380 \pm 0,008^{*}$ \\
\hline Права нирка & $0,345 \pm 0,007$ & $0,339 \pm 0,009$ & $0,331 \pm 0,006$ & $0,350 \pm 0,009$ \\
\hline Мозок & $0,675 \pm 0,015$ & $0,679 \pm 0,013$ & $0,663 \pm 0,038$ & $0,712 \pm 0,024$ \\
\hline
\end{tabular}

Примітка. * - достовірні відмінності від показників інших груп $(p \leq 0,05)$.

У піддослідних тварин, яких піддавали впливу препарату в концентрації 30,0 мг/м³, статистично достовірно зменшувався рівень гемоглобіну та гематокриту, паралельно знижувалось число еритроцитів та кількість ретикулоцитів. У крові щурів спостерігалась тенденція до зменшення, але невірогідного, кількості лейкоцитів, лімфоцитів, тромбоцитів, порівняно з аналогічними показниками тварин контрольної групи (табл. 5).

Таблиця 5. Гематологічні та біохімічні показники крові білих щурів при хронічному інтранзальному введенні лимонної кислоти

\begin{tabular}{|c|c|c|c|c|}
\hline \multirow{2}{*}{ Показники } & \multirow{2}{*}{ Контроль } & \multicolumn{3}{|c|}{ Експериментальні групи } \\
\hline & & $3,0 \mathrm{Mr} / \mathrm{M}^{3}$ & $10,0 \mathrm{Mr} / \mathrm{M}^{3}$ & $30,0 \mathrm{Mr} / \mathrm{M}^{3}$ \\
\hline 1 & 2 & 3 & 4 & 5 \\
\hline Гемоглобін, г/л & $156,8 \pm 6,13$ & $144,8 \pm 12,21$ & $136,8 \pm 5,07$ & $124,8 \pm 7,27^{*}$ \\
\hline Гематокрит, л/л & $0,443 \pm 0,025$ & $0,413 \pm 0,022$ & $0,383 \pm 0,029$ & $0,343 \pm 0,026 *$ \\
\hline Еритроцити, Т/л & $5,42 \pm 0,24$ & $5,41 \pm 0,4$ & $5,22 \pm 0,15$ & $4,14 \pm 0,29 *$ \\
\hline Лейкоцити, Г/л & $6,86 \pm 0,42$ & $6,62 \pm 0,4$ & $6,38 \pm 0,34$ & $6,8 \pm 0,46$ \\
\hline Базофіли, \% & 0 & 0 & 0 & 0 \\
\hline Еозинофіли, \% & $0,4 \pm 0,27$ & $0,2 \pm 0,22$ & $0,2 \pm 0,22$ & $0,4 \pm 0,27$ \\
\hline Паличкоядерні, \% & $6,6 \pm 0,57$ & $6,2 \pm 1,19$ & $6,4 \pm 0,57$ & $6,8 \pm 0,42$ \\
\hline Сегментоядерні, \% & $23,8 \pm 3,07$ & $26,2 \pm 2,27$ & $23,8 \pm 3,19$ & $25,8 \pm 1,52$ \\
\hline Моноцити, \% & $2,4 \pm 0,45$ & $1,8 \pm 0,42$ & $2,2 \pm 0,65$ & $2,4 \pm 0,57$ \\
\hline
\end{tabular}


Огляди літератури, оригінальні дослідження, погляд на проблему, випадок з практики, короткі повідомлення

Продовження табл. 5

\begin{tabular}{|l|c|c|c|c|}
\hline \multicolumn{1}{|c|}{1} & 2 & 3 & 4 & 5 \\
\hline Лімфоцити, \% & $53,4 \pm 3,58$ & $52,8 \pm 2,41$ & $54,6 \pm 4,13$ & $52,8 \pm 2,86$ \\
\hline Тромбоцити, $10^{9} / л$ & $448,8 \pm 22,84$ & $434,0 \pm 34,21$ & $456,0 \pm 43,21$ & $404,0 \pm 84,23$ \\
\hline АЛТ, ммоль/год.л & $3,0 \pm 0,28$ & $2,9 \pm 0,74$ & $3.60 \pm 1,18$ & $4,12 \pm 0,25 *$ \\
\hline АСТ, ммоль/год.л & $1,54 \pm 1,33$ & $1,53 \pm 1,12$ & $1,6 \pm 0,19$ & $1,62 \pm 0,7$ \\
\hline Сечовина, ммоль/л & $4,4 \pm 0,25$ & $4,32 \pm 0,42$ & $4,42 \pm 0,22$ & $4,44 \pm 0,28$ \\
\hline Креатинін, мкмоль/л & $40,80 \pm 1,49$ & $38,50 \pm 0,8$ & $33,20 \pm 2,57$ & $30,13 \pm 2,02^{*}$ \\
\hline Лужна фосф., Е/л & $269,70 \pm 19,9$ & $254,90 \pm 14,8$ & $270,40 \pm 15,8$ & $282,50 \pm 12,2^{*}$ \\
\hline Загальний білок, г/л & $66,4 \pm 2,38$ & $67,02 \pm 2,10$ & $69,3 \pm 2,04$ & $71,03 \pm 2,45^{*}$ \\
\hline
\end{tabular}

Примітка. * - достовірні відмінності від показників інших груп $(p \leq 0,05)$.

Результати біохімічних досліджень (табл. 5) свідчать про виражений вплив лимонної кислоти на перебіг фізіолого-біохімічних процесів в організмі тварин у концентрації 30 мг/м³ що супроводжуються підвищенням вмісту загального білка і зниженням креатиніну. У групі тварин, що піддавались впливу речовини в концентрація $3,0-10,0 \mathrm{mr} / \mathrm{M}^{3} \mathrm{He}$ відмічено достовірних відмінностей біохімічних показників від контролю.

Висновки. Враховуючи встановлені параметри токсичності лимонної кислоти, величину поро- гу гострої інгаляційної дії встановлено на рівні $200 \mathrm{Mr} / \mathrm{M}^{3}$, хронічної інгаляційної дії- $30 \mathrm{Mr} / \mathrm{M}^{3}$.

Характер токсичного ураження модельних організмів при інгаляційному надходженні лимонної кислоти дозволяє віднести сполуку до речовин із неспецифічною подразнювальною дією.

Перспективи подальших досліджень. Отримані дані дозволять у подальшому обґрунтувати гігієнічний регламент вмісту лимонної кислоти у повітрі робочої зони.

\section{ЛІТЕРАТУРА}

1. Citric acid: emerging applications of key biotechnology industrial product / R.Ciriminna, F. Meneguzzo, R. Delisi, M. Pagliaro // Chemistry Central Journal. - 2017. Vol. 11, №. 1. - P. 22.

2. New perspectives for citric acid production and application / C. R. Soccol, L. P. S. Vandenberghe, C. Rodrigues, A. Pandey // Food Technol and Biotechnology. 2006. - Vol. 44. - P. 141-149.

3. Hartwig A. MAK Commission. Citric acid and its alkali metal salts [MAK Value Documentation, 2018] / Hartwig A. // The MAK-Collection for Occupational Health and Safety: Annual Thresholds and Classifications for the Workplace. - 2002. - Vol. 3, No 4. - P. 1833-1846.

4. Safety Assessment of Citric Acid, Inorganic Citrate Salts, and Alkyl Citrate Esters as Used in Cosmetics / M. Fiume, B. Heldreth, W. Bergfeld [et al.] // International journal of toxicology. - 2014. - Vol. 33. - P. 16-46. $10.1177 / 1091581814526891$

5. The Short-term Effects of Single Toxic Dose of Citric Acid on the Mouse Tissues: Histopathological Study / T. Aktaç, A. Lu, E. Bakar, H. Karakafl // Fresenius Environmental Bulletin. - 2008. - Vol. 17. - P. 311-315.

6. Council of Europe. European Convention for the Protection of Vertebrate Animals used for Experimental

and other Scientific Purposes: explanatory report on the convention opened for signature on 18 March 1986. Council of Europe Press, 1993.

7. Matchinin A. A. Specific techniques of bronchoalveolar lavage collecting from laboratory animals / A. A. Matchinin, A. E. Katelnikova, K. L. Kryshen // Laboratory Animals for Science. - 2019. - Vol. 4. DOI: 10.29296/2618723X-2019-04-06.

8. Hadwan M. H. Data supporting the spectrophotometric method for the estimation of catalase activity / M. H. Hadwan, H. N. Abed // Data in brief. - 2015. - Vol. 6. P. 194-199. DOI: 10.1016/j.dib.2015.12.012.

9. Recknagel R. O. Spectrophotometric detection of lipid conjugated dienes / R. O. Recknagel, E. A. Glende // Methods Enzymol. - 1984. - 105. - P. 331-337.

10. Lipid peroxidation and antioxidant status in blood and tissue of malignant breast tumor and benign breast disease / A. Gönenç, D. Erten, S. Aslan [et al.] // Cell Biology International. - 2006. - Vol. 30 (4). - P. 376-380. DOI: 10.1016/j.cellbi.2006.02.005.

11. Glantz S. A. Primer of Applied Regression and Analysis of Variance / S. A. Glantz, B. K. Slinker- New York: McGraw-Hill, Health Professions Division, 1990. 
Огляди літератури, оригінальні дослідження, погляд на проблему, випадок з практики, короткі повідомлення REFERENCES

1. Ciriminna, R., Meneguzzo, F., Delisi, R., \& Pagliaro, M. (2017). Citric acid: emerging applications of key biotechnology industrial product. Chemistry Central Journal, $11(1), 22$.

2. Soccol, C.R., Vandenberghe, L.P.S., Rodrigues, C., \& Pandey, A. (2006). New perspectives for citric acid production and application. Food Technol and Biotechnology, 44, 141-149.

3. Hartwig, A., \& MAK Commission. (2002). Citric acid and its alkali metal salts [MAK Value Documentation, 2018]. The MAK-Collection for Occupational Health and Safety: Annual Thresholds and Classifications for the Workplace, 3 (4), 1833-1846.

4. Fiume, M., Heldreth, B., Bergfeld, W., Belsito, D., Hill, R., Klaassen, C., \& Snyder, P. (2014). Safety Assessment of Citric Acid, Inorganic Citrate Salts, and Alkyl Citrate Esters as Used in Cosmetics. International Journal of Toxicology, 33. 16-46. 10.1177/1091581814526891

5. Aktaç, T., Lu, A., Bakar, E., \& Karakafl, H. (2005). The short-term effects of single toxic dose of citric acid in mice. Fresenius Environmental Bulletin, 17, 311-315.

6. Council of Europe. (1986). European Convention for the Protection of Vertebrate Animals used for Experi-

mental and other Scientific Purposes: explanatory report on the convention opened for signature on 18 March 1986. Council of Europe Press.

7. Matchinin, A.A., Katelnikova, A.E., \& Kryshen, K.L. (2019). Specific techniques of bronchoalveolar lavage collecting from laboratory animals. Laboratory Animals for Science, 4. doi:10.29296/2618723X-2019-04-06

8. Hadwan, M. H., \& Abed, H. N. (2015). Data supporting the spectrophotometric method for the estimation of catalase activity. Data in brief, 6, 194-199. DOl:10.1016/j. dib.2015.12.012

9. Recknagel, R.O., \& Glende, E.A. (1984). Spectrophotometric detection of lipid conjugated dienes. Methods Enzymol., 105, 331-337.

10. Gönenç, A., Erten, D., Aslan, S., Akıncı, M., Şimşek, B. \& Torun, M. (2006). Lipid peroxidation and antioxidant status in blood and tissue of malignant breast tumor and benign breast disease. Cell Biology International, 30, 376-380. https://doi.org/10.1016/j.cellbi.2006.02.005

11. Glantz, S. A., \& Bryan K. S. (1990). Primer of Applied Regression and Analysis of Variance (3nd ed.). NY-Toronto: McGraw-Hill, Inc.

\title{
ОЦЕНКА БИОЛОГИЧЕСКИХ ЭФФЕКТОВ ИНГАЛЯЦИОННОГО ВОЗДЕЙСТВИЯ ЛИМОННОЙ КИСЛОТЫ (ЭКСПЕРИМЕНТАЛЬНЫЕ ДАННЫЕ)
}

\author{
๑В. А. Туркина, Н. Ф. Лукасевич, О. С. Корчинская, С. Ш. Жук \\ Львовский национальный медицинский университет имени Данила Галицкого
}

РЕЗЮМЕ. Несмотря на широкое и крупнотоннажное применение лимонной кислоты и, соответственно, активный производственный контакт с ней работников, занятых на производстве, данных литературы относительно биологических эффектов аэрозоля порошка лимонной кислоты при ингаляционном воздействии крайне мало.

Цель - установить биологические эффекты лимонной кислоты при однократном и многократном ингаляционном поступлении с последующим установлением безопасных уровней воздействия.

Материал и методы. Экспериментальное исследование выполнено на нелинейных белых крысах. Иссле-

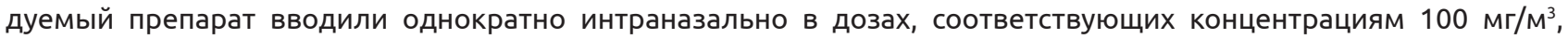
$200 \mathrm{Mr} / \mathrm{M}^{3}, 400 \mathrm{Mr} / \mathrm{M}^{3}$ и в течение 6-ти месяцев в дозах, соответствующих концентрациям $30 \mathrm{Mr} / \mathrm{M}^{3}, 10 \mathrm{Mr} / \mathrm{M}^{3}, 3 \mathrm{Mr} / \mathrm{M}^{3}$. Критериями для определения токсического воздействия на организм животных в эксперименте были общее состояние животных, морфологические показатели органов, гематологические и биохимические показатели крови, показатели перекисного окисления липидов. Процессы оксидативного стресса оценивали по показателям перекисного окисления липидов. Влияние на глубокие дыхательные пути оценивали по цитологическому составу жидкости бронхоальвеолярного лаважа.

Результаты. Как свидетельствуют результаты исследований, лимонная кислота при однократном и хроническом ингаляционном поступлении вызвала одновременно нарушения как функционального состояния дыхательной системы, так и показателей гемостаза, ее можно отнести к веществам с неспецифическим раздражающим действием. Результаты биохимических исследований свидетельствуют о выраженном влиянии лимонной кислоты на течение физиолого-биохимических процессов в организме животных в концентрациях 400 мг/м³ при однократном воздействии и 30 мг/м³ при многократном ингаляционном поступлении, и сопровождаются повышением активности сывороточной трансаминазы, содержания общего белка и снижением креатинина. Также данные концентрации вызывали снижение числа эритроцитов, уровня гематокрита и количества ретикулоцитов. В бронхоальвеолярной жидкости высокие испытанные концентрации лимонной кислоты вызвали снижение процентного содержания макрофагов и повышение лимфоцитов.

Выводы. Учитывая установленные параметры токсичности, величину порога острого ингаляционного действия установили на уровне $200 \mathrm{mг} / \mathrm{M}^{3}$, хронического ингаляционного действия - 30 мг/м³. Характер токсического поражения органов экспериментальных животных при ингаляционном поступлении лимонной кислоты позволяет отнести соединение к веществам с неспецифическим раздражающем действием.

КЛЮЧЕВЫЕ СЛОВА: лимонная кислота; ингаляционное влияние; пороговые концентрации. 
Огляди літератури, оригінальні дослідження, погляд на проблему, випадок з практики, короткі повідомлення

\title{
EVALUATION OF BIOLOGICAL EFFECTS OF INHALATION EFFECT OF CITRIC ACID (EXPERIMENTAL DATA)
}

\author{
○V. A. Turkina, N. F. Lukasevych, O. S. Korchynska, S. Sh. Zhuk \\ Danylo Halytsky Lviv National Medical University
}

RESUME. Despite the wide and multi-ton use of citric acid and, accordingly, active industrial contact with it by workers, the literature data on the biological effects of aerosol of citric acid powder by inhalation is extremely small.

The aim - to investigate the biological effects of citric acid with single and multiple inhalation to establish safe levels of exposure.

Material and Methods. The experimental study was performed on nonlinear white rats. The test substance was administered once intranasally in doses corresponding to concentrations of $100 \mathrm{mg} / \mathrm{m}^{3}, 200 \mathrm{mg} / \mathrm{m}^{3}, 400 \mathrm{mg} / \mathrm{m}^{3}$ and for 6 months in doses corresponding to concentrations of $30 \mathrm{mg} / \mathrm{m}^{3}, 10 \mathrm{mg} / \mathrm{m}^{3}, 3 \mathrm{mg} / \mathrm{m}^{3}$. Criteria for determining the toxic effect on animals in the experiment were: general condition of animals, morphological parameters of organs, hematological and biochemical parameters of blood, indicators of lipid peroxidation. Oxidative stress processes were assessed by lipid peroxidation indicators. The effect on the deep respiratory tract was assessed by the cytological composition of the broncho-alveolar lavage fluid.

Results. According to the results of research, citric acid in a single and chronic inhalation intake caused a violation of both the functional state of the respiratory system and hemostasis at the same time. It can be attributed to substances with non-specific irritant action. The results of biochemical studies indicate a pronounced effect of citric acid on physiological and biochemical processes in animals at concentrations of $400 \mathrm{mg} / \mathrm{m}^{3}$ with a single exposure and $30 \mathrm{mg} / \mathrm{m}^{3}$ with multiple inhalation, which are accompanied by increased activity of serum transaminases, total protein content and decreased creatinine. These concentrations caused a decrease in erythrocyte count, hematocrit level and reticulocyte count too. The highest concentrations of citric acid caused a decrease in the percentage of macrophages and an increase in lymphocytes in the bronchoalveolar fluid.

Conclusions. According to the established parameters of citric acid toxicity, the value of the threshold of acute inhalation action is set at $200 \mathrm{mg} / \mathrm{m}^{3}$, chronic inhalation action $-30 \mathrm{mg} / \mathrm{m}^{3}$.

The nature of toxic lesions of the organs of experimental organisms during inhalation of citric acid allows the compound to be classified as a substance with non-specific irritant effect.

KEY WORDS: citric acid; inhalation effect; threshold concentrations. 